\title{
Protective role of metallothionein in benzo[a]pyrene-induced DNA damage
}

\author{
Masaki Takaishi', Masumi Sawada², Akinori Shimada², Junko S.Suzuki, \\ Masahiko Satoh ${ }^{1,4}$ and Hisamitsu Nagase ${ }^{1}$ \\ ${ }^{1}$ Laboratory of Hygienics, Gifu Pharmaceutical University, 5-6-1 Mitahora-higashi, Gifu City, Gifu 502-8585, Japan \\ ${ }^{2}$ Department of Veterinary Pathology, Tottori University, 4-101 Koyama-minami, Tottori City, Tottori \\ 680-8553, Japan \\ ${ }^{3}$ Research Center for Environmental Risk, National Institute for Environmental Studies, 16-2 Onogawa, Tsukuba, \\ Ibaraki 305-8506, Japan \\ ${ }^{4}$ Laboratory of Pharmaceutical Health Sciences, School of Pharmacy, Aichi Gakuin University, 1-100 Kusumoto-cho, \\ Chikusa-ku, Nagoya, Aichi 464-8650, Japan
}

(Received March 13, 2009; Accepted June 2, 2009)

\begin{abstract}
Metallothionein (MT) is known to reduce chemical carcinogenesis. Carcinogenesis induced by benzo $[a]$ pyrene $(\mathrm{B}[a] \mathrm{P})$ which is an environmental chemical carcinogen is related to DNA adduct formation and oxidative damage through metabolic activation. Ten-week-old male MT-I/II null mice and wild-type mice were given a single injection of $\mathrm{B}[a] \mathrm{P}(250 \mathrm{mg} / \mathrm{kg}$, p.o. $)$, and $\mathrm{B}[a] \mathrm{P}$-induced DNA damage was evaluated at 6-48 hr later. The frequencies of micronucleated reticulocytes (MNRET) in MT-I/II null mice were significantly increased compared with that of wild-type mice at $48 \mathrm{hr}$ after B[a]P administration. At $48 \mathrm{hr}$ after $\mathrm{B}[a] \mathrm{P}$ administration, comet scores were significantly increased in MT-I/II null mice but not in wild-type mice. 8-Hydroxy-2'-deoxyguanosine (8-OHdG), a biomarker of oxidative DNA damage, was significantly increased in liver of MT-I/II null mice at 6 and $12 \mathrm{hr}$ after B[a]P administration, although that of wild-type mice was only slightly changed. Because cytochrome P450 (CYP) plays a major role in the process of $\mathrm{B}[a] \mathrm{P}$ metabolic activation, we attempted to reveal the effect of MT on metabolic activation of $\mathrm{B}[a] \mathrm{P}$. Although CYP1A activities were elevated in the livers of MT-I/II null mice and wild-type mice treated with $\mathrm{B}[a] \mathrm{P}$, it was not different between both strains of mice. In addition, MT levels in the livers of wild-type mice were significantly increased by the $\mathrm{B}[a] \mathrm{P}$ treatment, whereas MT was not detected in livers of MT-I/II null mice with or without $\mathrm{B}[a] \mathrm{P}$ treatment. These results demonstrate that MT acts as an endogenous defensive factor against B $[a]$ P-induced DNA damage.
\end{abstract}

Key words: MT, $\mathrm{B}[a] \mathrm{P}$, Micronucleus test, Comet assay, 8-OHdG, EROD activity

\section{INTRODUCTION}

Benzo $[a]$ pyrene $(\mathrm{B}[a] \mathrm{P})$ is one of the polycyclic aromatic hydrocarbons (PAH) referred to as a human carcinogen (IARC monographs, in preparation). $\mathrm{B}[a] \mathrm{P}$ has been shown to induce gene mutations, chromosomal aberrations and other types of genotoxic effects in in vitro and in vivo. Most humans are more or less constantly exposed to $\mathrm{B}[a] \mathrm{P}$. As a product of incomplete combustion, $\mathrm{B}[a] \mathrm{P}$ is present in tobacco smoke, diesel engine exhaust, urban air, various types of processed foods, coal-tar, creosote, asphalt, and various occupational settings such as coal gasification plants, coke ovens and iron foundries.
$\mathrm{B}[a] \mathrm{P}$ is metabolized to 7,8-dihydroxy-9,10-epoxy7,8,9,10-tetrahydrobenzo[a]pyrene (BPDE) by cytochrome P450 (P450 or CYP). BPDE is the ultimate carcinogenic form of $\mathrm{B}[a] \mathrm{P}$ and binds to the exocyclic nitrogen of deoxyguanosine in DNA. BPDE-DNA adducts in target tissues were closely related to development of cancer in animals and humans (Culp and Beland, 1994). In addition, oxidative DNA damage also plays an important role in the process of $\mathrm{B}[a] \mathrm{P}$ carcinogenesis, because $\mathrm{B}[a] \mathrm{P}$ produces quinone derivatives which easily generate reactive oxygen species (ROS) and oxidatively damage DNA (Penning et al., 1996). As a result of hydroxyl radical interaction with DNA, many types of oxidized

Correspondence: Hisamitsu Nagase (E-mail: nagase@gifu-pu.ac.jp) 
nucleosides have been reported (Poulsen et al., 1998). 8Hydroxy-2'-deoxyguanosine (8-OHdG) is one of the oxidative DNA modifications and is extensively used for study of mutagenicity (Cheng et al., 1992).

Metallothionein (MT) is a cysteine-rich low-molecular weight protein with a high affinity for metals such as zinc, copper, cadmium and mercury (Miles et al., 2000). There are four isoforms of MT, namely MT-I, MT-II, MTIII and MT-IV. MT-I and MT-II are expressed in all tissues (Miles et al., 2000). MT-III is expressed mainly in the brain and MT-IV in squamous epithelia. MT has been known to be involved in many physiological and pathophysiological processes such as intracellular storage, transport and metabolism of heavy metals, regulating essential trace metal homeostasis and playing a protective role in heavy metal toxicity (Miles et al., 2000). MT also plays a protective role against toxicity of free radical-inducing agents such as paraquat, adriamycin and ionizing radiation (Satoh et al., 1988, 1992; Sato and Bremner, 1993; Cai et al., 1999). Detailed examinations of MT with free radicals have been extensively undertaken and have demonstrated that MT is a potent antioxidant to prevent various oxidative injuries from reactive oxygen and nitrogen species in vitro and in vivo (Sato and Bremner, 1993; Cai et al., 1999, 2000). In addition, MT can reduce the adverse effects of the chemotherapeutic agents adriamycin and cis-diamminedichloroplatinum (II) (cisplatin) and other alkylating agents. (Satoh et al., 1988; Naganuma et al., 1987; Nakagawa et al., 1995).

Pretreatment with MT-inducing metals such as zinc and bismuth can suppress chemical carcinogenesis caused by 7,12-dimethylbenz[a]anthracene (DMBA), 3methyl cholanthrene, cisplatin and melphalan (Poswillo and Cohen, 1971; Duncan and Dreosti, 1975; Satoh et al., 1993; Cherian et al., 1994). Also the incidence of Xray-induced thymic lymphomas was lowered by administration of bismuth nitrate as an MT inducer (Cai et al., 1999). Recently, Cherian et al. (2003) have reported that high expression of MT in certain tumors may block apoptosis and may be related to tumor progression; a central role for p53 is to act as a tumor suppressor by inducing apoptosis.

Recently, MT-I/II null mice with both MT-I and MTII null mutations have been developed and widely used in toxicological experiments (Michalska and Choo, 1993). Some researchers have reported that MT-I/II null mice were more susceptible than wild-type mice in chemicaland metal-induced carcinogenesis (Zhang et al., 1998; Kondo et al., 1999; Suzuki et al., 2003; Waalkes et al., 2004).

However, the involvement of MT in the genotoxicity of $\mathrm{B}[a] \mathrm{P}$ is not clear. MT-I/II null mice have been proven to be a good tool for elucidation of the normal functions of MT and the consequences of MT deficiency. In the present study, to elucidate the genotoxicity of $\mathrm{B}[a] \mathrm{P}$ and the ability of MT to modify $\mathrm{B}[a] \mathrm{P}$ toxicity, we investigated the susceptibility of MT-I/II null mice to $\mathrm{B}[a] \mathrm{P}$ induced DNA damage such as chromosomal aberrations, DNA strand breaks and oxidative DNA damage.

\section{MATERIALS AND METHODS}

\section{Chemicals}

$\mathrm{B}[a] \mathrm{P}$, nuclease $\mathrm{P}_{1}$ and alkaline phosphatase were purchased from Sigma Chemicals Co. (St. Louis, MO, USA). A DNA Extractor WB Kit was purchased from Wako Pure Chemical Industries, Ltd. (Osaka, Japan). An 8OHdG ELISA kit (8-OHdG Check High sensitivity) and 8-OHdG antibody were purchased from Japan Institute for the Control of Aging (Shizuoka, Japan).

\section{Animals}

MT-I/II null mice were kindly provided by Dr. K.H.A. Choo (Murdoch Institute for Research into Birth Defects, Royal Children's Hospital, Australia) and were of a mixed genetic background of 129 Ola and C57BL/6 strains (Michalska and Choo, 1993). F1 hybrid mice were mated with C57BL/6 mice and their offspring were backcrossed to $\mathrm{C} 57 \mathrm{BL} / 6$ for six generations. Both MT-I/II null mice and wild-type mice were generated by matings of heterozygous mice.

MT-I/II null mice and wild-type mice were routinely bred in the vivarium of the Gifu Pharmaceutical University. Both strains of mice were housed in cages in ventilated animal rooms with a controlled temperature of $24 \pm$ $2^{\circ} \mathrm{C}$, a relative humidity of $55 \pm 10 \%$ and a $12 \mathrm{hr}$ light/ dark cycle. The mice were maintained on standard laboratory chow and tap water ad libitum, and they received humane care throughout the experiment according to the guidelines of the Gifu Pharmaceutical University.

\section{Treatments}

Ten-week-old male MT-I/II null mice and wild-type mice were randomized into control and experimental groups (the groups of $0,12,24$ and $48 \mathrm{hr}$ after $\mathrm{B}[a] \mathrm{P}$ administration on MT-I/II null mice consisted of 4 mice and the other group consisted of 5 mice). The groups of mice were given a single oral administration of $\mathrm{B}[a] \mathrm{P}$ at a dose of $250 \mathrm{mg} / \mathrm{kg}$. Peripheral blood was collected from the mouse tail vein, and then the liver and bone marrow were removed from each mouse under diethyl ether anesthesia at $0,6,12,24$ and $48 \mathrm{hr}$ after the injection. 
Protection from DNA damage by metallothionein

Another group of mice were orally administered a single dose of $\mathrm{B}[\mathrm{a}] \mathrm{P}$ at a dose of 30 to $750 \mathrm{mg} / \mathrm{kg}$. Peripheral blood was collected from the mouse tail vein under diethyl ether anesthesia at $48 \mathrm{hr}$ after injection.

\section{Micronucleus test}

The peripheral blood smeared on a slideglass (Matsunami Glass Industries, Osaka, Japan) was stained with acridine orange according to the method described by Hayashi et al. (1990). For each animal, 1,000 reticulocytes (RET) were scored for the micronucleus (MN) and the frequencies of micronucleated reticulocytes (MNRET) were expressed as percent of RET.

\section{Single cell gel electrophoresis (comet) assay}

The liver was gently homogenized according to the method described by Sasaki et al. (1997) with some modification. The slide preparation and electrophoresis were done according to the method described by Singh et al. (1988) with some modification.

Fifty nuclei were examined at 200 magnification using a fluorescene microscope equipped with a green filter. To quantify the average DNA strand breaks, all of them were classified into one of the following groups: only the head (normal; score $=0)$; tail length $<$ head length $($ score $=1$ ); tail length $<2 \times$ head length $($ score $=2)$; tail length $<3 \times$ head length $($ score $=3)$. Comet scores were the calculated sum of 50 nuclei.

\section{Determination of 8-OHdG in DNA}

The DNA was extracted from the liver with the DNA Extractor WB Kit according to the method of Kasai et al. (1987). DNA concentration was determined by the absorbance at $260 \mathrm{~nm}\left(\mathrm{~A}_{260} 1.0=50 \mu \mathrm{g}\right.$ DNA). The absorbance ratio $\left(\mathrm{A}_{260} / \mathrm{A}_{280}\right)$ was between 1.80 and 1.85 . The extracted DNA was digested with 6 units of nuclease $\mathrm{P}_{1}$ and 200 $\mathrm{mM}$ sodium acetate $(\mathrm{pH} 4.8)$ at $37^{\circ} \mathrm{C}$ for $1 \mathrm{hr}$. The samples were incubated at $37^{\circ} \mathrm{C}$ for $1 \mathrm{hr}$ after 2 units of alkaline phosphatase and $1 \mathrm{M}$ Tris- $\mathrm{HCl}(\mathrm{pH} 7.4)$ were added.

The amounts of $8-\mathrm{OHdG}$ in the liver were measured by an ELISA kit according to the manufacturer's instructions. 8-OHdG amounts were presented as the 8-OHdG $\mu \mathrm{g} / \mathrm{g}$ DNA ratio.

\section{Immunohistochemical detection of 8-OHdG}

The liver was fixed in $10 \%$ neutral buffered formalin solution and processed for paraffin embedding. Tissue 5 - $\mu \mathrm{m}$ sections were prepared and placed on a slide glass (Matsunami Glass Industries, Osaka, Japan) and deparaffinized using xylene. Tissue sections were treated with $3 \%$ hydrogen peroxide for $15 \mathrm{~min}$ and washed with
$0.01 \mathrm{M}$ PBS. Mouse anti 8-OHdG antibody (1:400) was applied to each section at $4^{\circ} \mathrm{C}$ overnight.

\section{Hepatic CYP1A enzymatic activity}

7-Ethoxyresorufin- $O$-deethylation (EROD) activity in liver microsomes was determined by the method of Shimada et al. (1998). The EROD activity was expressed in nanomoles of resorufin formed per minutes per $\mathrm{mg}$ of proteins.

\section{MT concentration measurement}

MT (MT-I and MT-II isoforms) concentrations in the liver were measured by radioimmunoassay (Tohyama and Shaikh, 1981) as modified by Nishimura et al. (1990) using sheep anti-rat MT-I antiserum. Ten \% liver homogenate was prepared in $10 \mathrm{mM}$ Tris- $\mathrm{HCl}$.

\section{Statistical analysis}

All values are expressed as the mean \pm S.D.. Differences in the mean values were assessed by the ANOVA test followed by Newman-Keuls tests for post hoc comparison. Differences were considered statistically significant at $p<0.05$.

\section{RESULTS}

\section{MN test}

The results of the MN test, which is an indicator of chromosomal aberration, are shown in Fig. 1. The frequencies of MNRET were significantly increased in the MT-I/II null mice at $48 \mathrm{hr}$ after the $\mathrm{B}[a] \mathrm{P}(250 \mathrm{mg} / \mathrm{kg})$ administration (Fig. 1A). However, the frequencies of MNRET in wild-type mice were not increased by the $\mathrm{B}[a] \mathrm{P}$ treatment.

Fig. 1B shows the effect of various doses of $\mathrm{B}[a] \mathrm{P}$ on $\mathrm{MN}$ induction at $48 \mathrm{hr}$ after administration. The frequencies of MNRET in both MT-I/II null mice and wildtype mice were increased by $\mathrm{B}[a] \mathrm{P}$ treatment in a dosedependent manner up to the dose of $250 \mathrm{mg} / \mathrm{kg}$. At 125 and $250 \mathrm{mg} / \mathrm{kg}$ of $\mathrm{B}[\mathrm{a}] \mathrm{P}$ administration, the frequencies of MNRET were significantly increased in the MTI/II null mice but not in the wild-type mice. At doses of 500 and $750 \mathrm{mg} / \mathrm{kg} \mathrm{B}[\mathrm{a}] \mathrm{P}$, the frequencies of MNRET in MT-I/II null mice were significantly increased compared with those in wild-type mice. As for the MT-I/II null mice treated with $750 \mathrm{mg} / \mathrm{kg} \mathrm{B}[a] \mathrm{P}$, two out of five mice died within $48 \mathrm{hr}$ after administration.

\section{Comet assay}

Comet scores, an indicator of DNA strand breaks, in the MT-I/II null mice were significantly increased at 48 
A

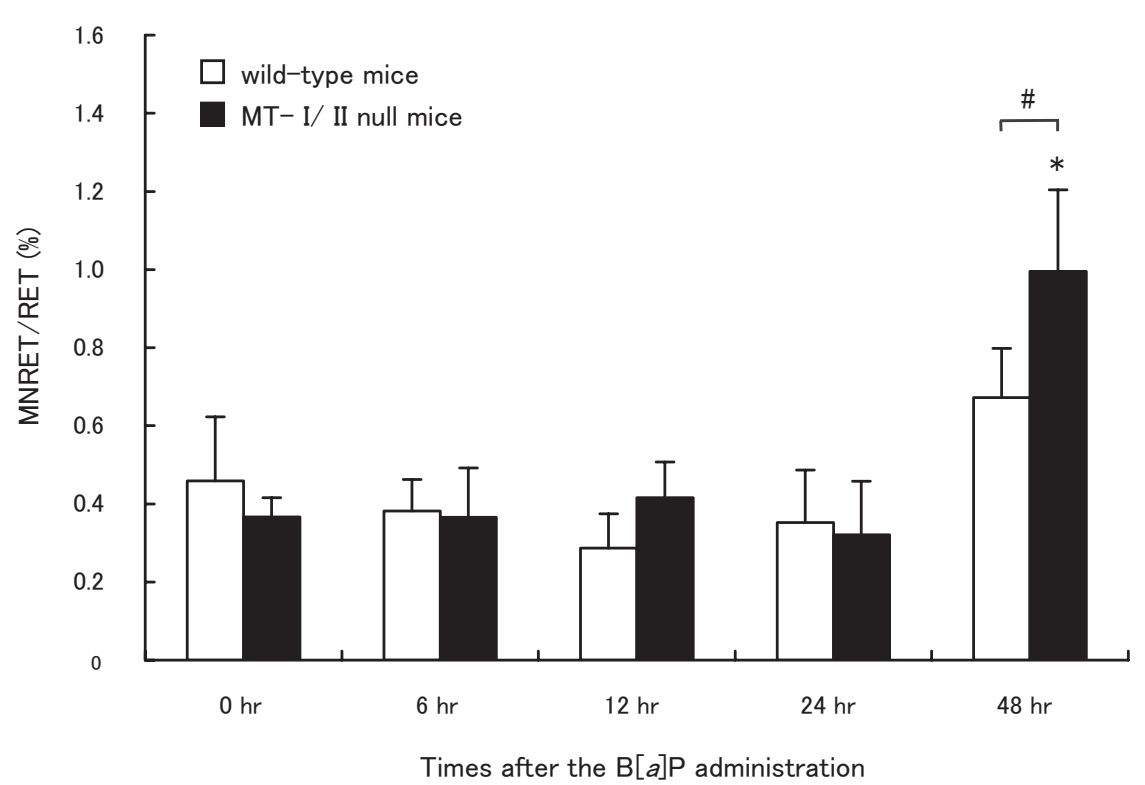

B

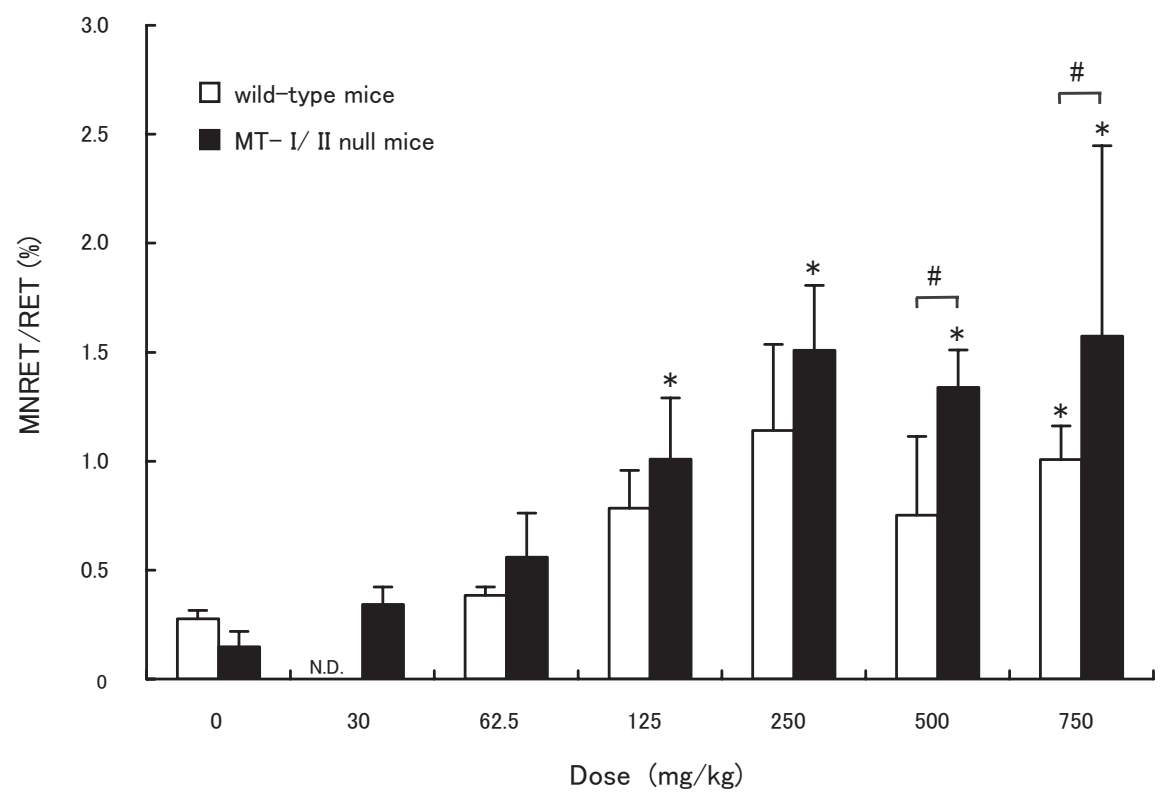

Fig. 1. Frequencies of MNRET in peripheral blood of MT-I/II null mice and wild-type mice treated with B[a]P. (A) Times changed after $\mathrm{B}[a] \mathrm{P}$ treatment. (B) Dose changed $\mathrm{B}[a] \mathrm{P}$ treatment. Values are represented as mean \pm S.D.. * Statistically significant differences from the corresponding control group $(p<0.05)$. \#Statistically significant differences from the dose or timesmatched MT-I/II null mouse group $(p<0.05)$. N.D.: not done.

hr after $\mathrm{B}[a] \mathrm{P}$ administration (Fig. 2). In contrast, comet scores in the wild-type mice were not increased by $\mathrm{B}[a] \mathrm{P}$ treatment.

\section{Determination of $\mathbf{8 - O H d G}$}

The 8-OHdG levels, an indicator of oxidative DNA damage, in the livers of MT-I/II null mice, were signifi- 


\section{Protection from DNA damage by metallothionein}

cantly increased compared with those in wild-type mice at 6 and $12 \mathrm{hr}$ after $\mathrm{B}[a] \mathrm{P}$ administration (Fig. 3). At 6 and $12 \mathrm{hr}$ after $\mathrm{B}[a] \mathrm{P}$ administration, 8-OHdG levels in the livers of MT-I/II null mice were 4-fold and 2.5-fold higher than those in wild-type mice, respectively.

The 8 -OHdG immunoreactivity in the livers of MT-

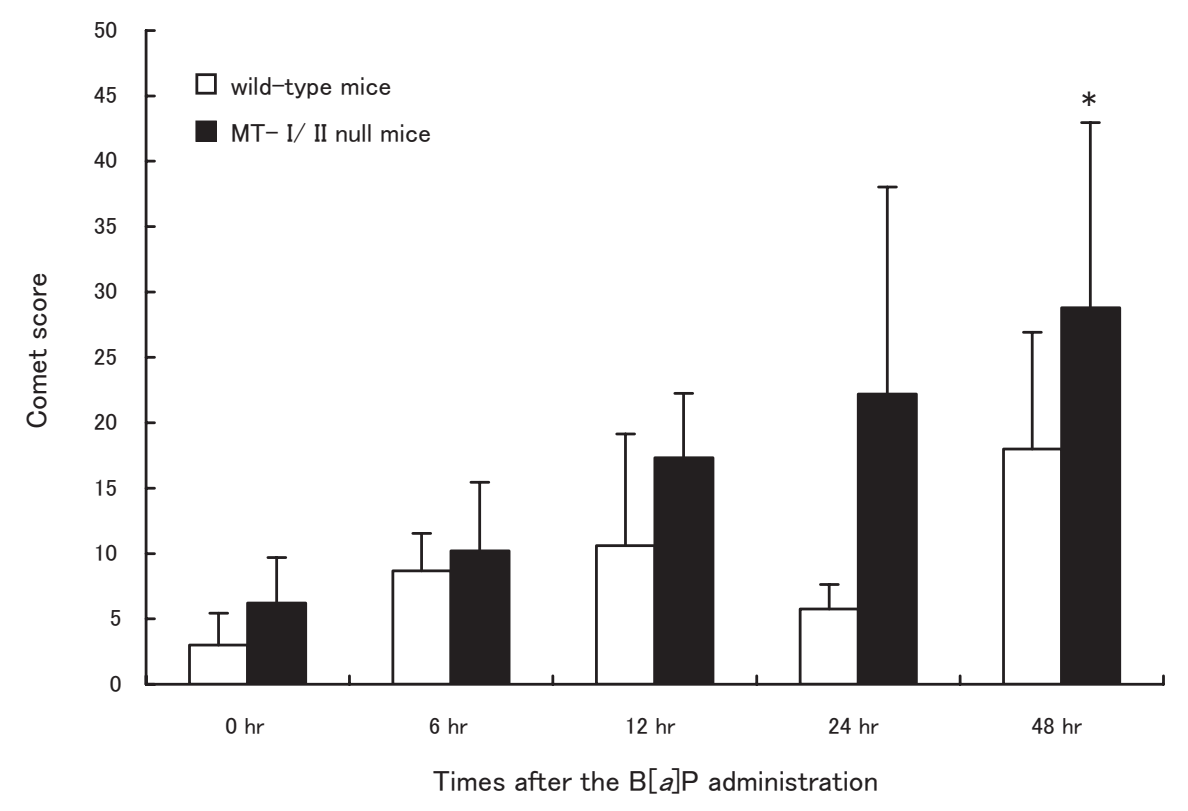

Fig. 2. Comet scores in the livers of MT-I/II null mice and wild-type mice treated with $\mathrm{B}[a] \mathrm{P}$. Values are represented as mean \pm S.D.. ${ }^{*}$ Statistically significant differences from the corresponding control group $(p<0.05)$.

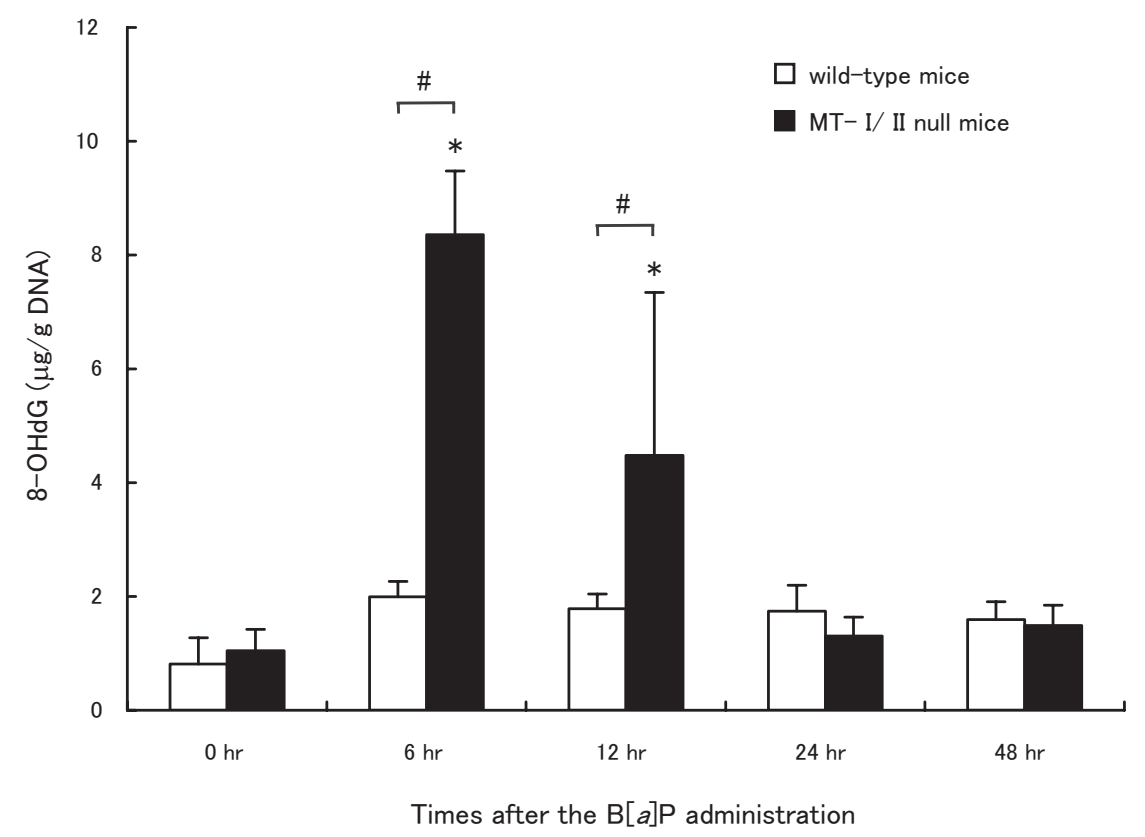

Fig. 3. 8-OHdG levels in the livers of MT-I/II null mice and wild-type mice treated with $\mathrm{B}[a] \mathrm{P}$. Values are represented as mean \pm S.D.. * Statistically significant differences from the corresponding control group $(p<0.05)$. " Statistically significant differences from the dose-matched MT-I/II null mouse group $(p<0.05)$. 


\section{Takaishi et al.}

$\mathrm{I} / \mathrm{II}$ null mice and wild-type mice treated with $\mathrm{B}[a] \mathrm{P}$ is shown in Fig. 4. Little 8-OHdG was detected in the livers of untreated wild-type mice and MT-I/II null mice (Figs. 4A and F). In wild-type mice, $8-\mathrm{OHdG}$ in the liv- er was slightly increased only at $12 \mathrm{hr}$ after $\mathrm{B}[a] \mathrm{P}$ administration (Fig. 4C). In contrast, 8-OHdG in the livers of MT-I/II null mice was apparently increased at 6 and $12 \mathrm{hr}$ after administration (Figs. 4G and $\mathrm{H}$ ).

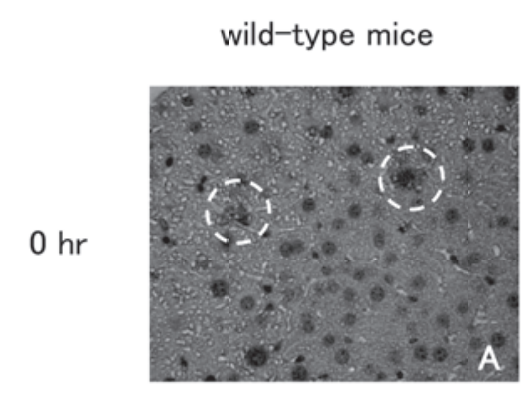

MT-I/II null mice
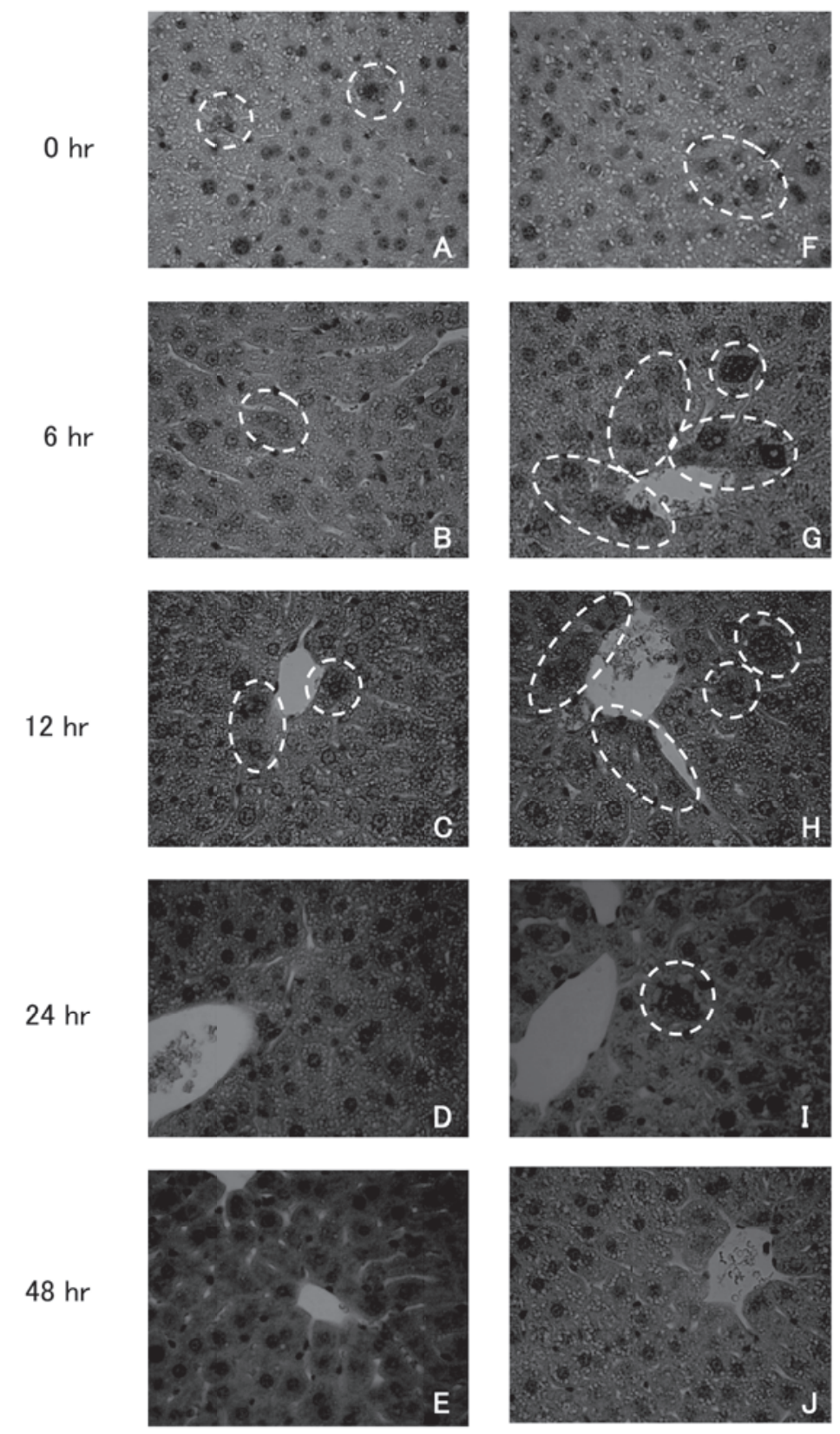

Fig. 4. Immunohistochemical staining for $8-\mathrm{OHdG}$ in livers obtained from $\mathrm{B}[a] \mathrm{P}$ treated MT-I/II null mice and wild-type mice. (A) and (F), 0 hr after $\mathrm{B}[a] \mathrm{P}$ administration. (B) and (G), $6 \mathrm{hr}$ after $\mathrm{B}[a] \mathrm{P}$ administration. (C) and (H), $12 \mathrm{hr}$ after $\mathrm{B}[a] \mathrm{P}$ administration. (D) and (I), $24 \mathrm{hr}$ after $\mathrm{B}[a] \mathrm{P}$ administration. (E) and (J), $48 \mathrm{hr}$ after $\mathrm{B}[a] \mathrm{P}$ administration. (A) to (E), wild-type mice. (F) to (J), MT-I/II null mice. 8-OHdG is indicated by white circles. Magnification; $\mathrm{x} 200$. 
Protection from DNA damage by metallothionein

\section{Evaluation of hepatic CYP1A enzymatic activity}

Hepatic EROD activities were significantly increased in both MT-I/II null mice and wild-type mice at 12, 24 and $48 \mathrm{hr}$ after $\mathrm{B}[a] \mathrm{P}$ administration (Fig. 5). However, the hepatic EROD activities of $\mathrm{B}[a] \mathrm{P}$-administered mice were not changed between the MT-I/II null mice and wild-type mice.

\section{MT concentration in the liver}

MT concentrations were determined in the livers of wild-type mice and MT-I/II null mice treated with $\mathrm{B}[a] \mathrm{P}$. The hepatic MT levels in the wild-type mice were signif- icantly increased by $\mathrm{B}[a] \mathrm{P}$ treatment. However, MT was not detected in the livers of MT-I/II null mice with or without $\mathrm{B}[a] \mathrm{P}$ treatment (Table 1).

\section{DISCUSSION}

Because $\mathrm{B}[a] \mathrm{P}$ is known to induce chromosomal aberration, many investigators have used the $\mathrm{MN}$ test for detecting $\mathrm{B}[a] \mathrm{P}$ mutagenicity in vivo (Shimada et al., 1992). In the present study, MT-I/II null mice are more susceptible to chromosomal aberration than wild-type mice at various doses of $\mathrm{B}[a] \mathrm{P}$. Itoh and Shimada (1996)

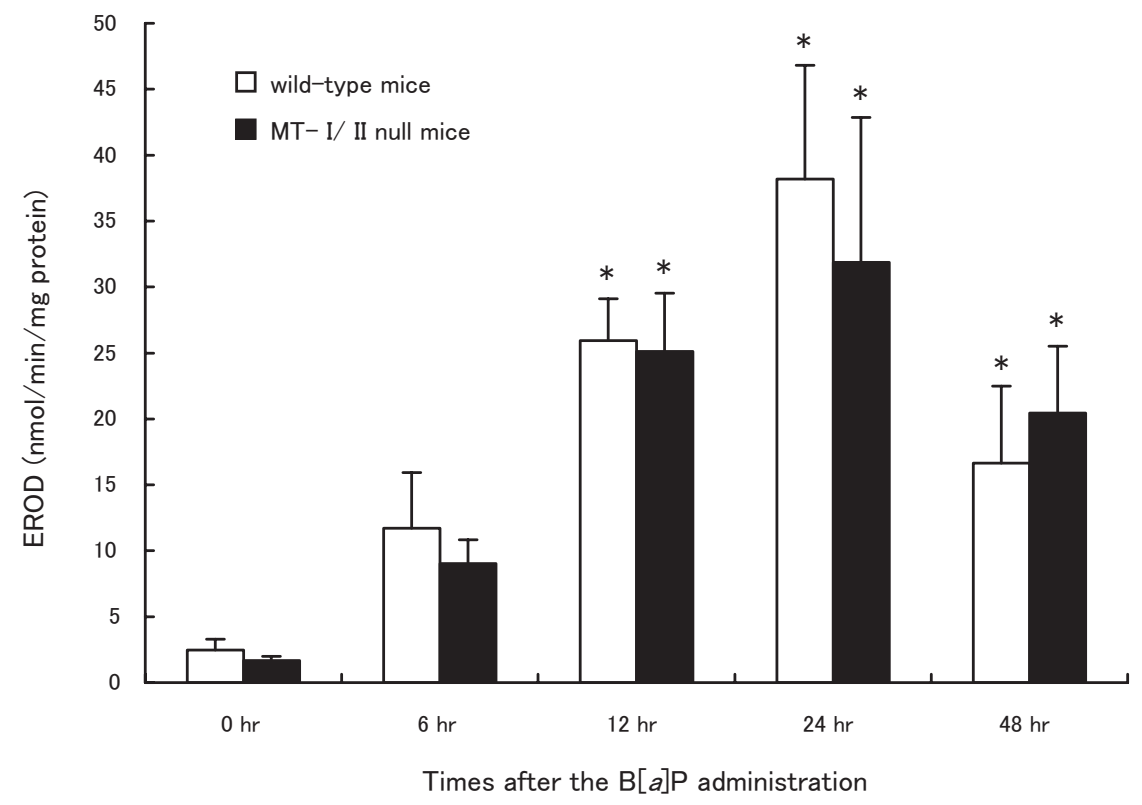

Fig. 5. EROD activities in the livers of MT-I/II null mice and wild-type mice treated with B $[a] \mathrm{P}$. Values are represented as mean \pm S.D.. * Statistically significant differences from the corresponding control group $(p<0.05)$.

Table 1. MT levels in the livers of MT-I/II null mice and wild-type mice treated with $\mathrm{B}[a] \mathrm{P}$

\begin{tabular}{llc}
\hline \multirow{2}{*}{ Times after B $[a]$ P administration } & \multicolumn{2}{c}{ MT concentrations $(\mu \mathrm{g} / \mathrm{g}$ tissue) } \\
\cline { 2 - 3 } $0 \mathrm{hr}$ & wild-type mice & MT-I/II null mice \\
$6 \mathrm{hr}$ & $10.51 \pm 4.21$ & N.D. \\
$12 \mathrm{hr}$ & $41.67 \pm 10.55^{*}$ & N.D. \\
$24 \mathrm{hr}$ & $40.09 \pm 2.12^{*}$ & N.D. \\
$48 \mathrm{hr}$ & $29.98 \pm 8.34^{*}$ & N.D. \\
\hline
\end{tabular}

Values are means \pm S.D.. Statistically significant differences from control group.

Limit of detection for MT assay is $1.85 \mu \mathrm{g} / \mathrm{g}$ tissue. N.D.: not detected.

${ }^{*} \mathrm{p}<0.05$. 
have reported that pretreatment with an MT inducer suppressed the $\mathrm{MN}$ induction by chromium compounds and selenium compounds. MN induced by anticancer drugs such as cisplatin, adriamycin, cyclophosphamide and Lphenylalanine mustard was also prevented by pretreatment with MT inducers (Nakagawa et al., 1995). These results suggest that MT may play a protective role against chromosomal aberration induced by several compounds including $\mathrm{B}[a] \mathrm{P}$.

Comet assay is a very sensitive technique for detecting individual eukaryote cells of multiple classes of DNA damage and incomplete excision repair sites associated with the elimination of DNA damage (Fairbairn et al., 1995). Sasaki et al. (1997) used the comet assay to detect DNA damage by various mutagens and found that hepatic DNA strand breaks were increased by oral administration of $\mathrm{B}[a] \mathrm{P}$. In DNA strand breaks caused by dimethylarsinic acid, MT-I/II null mice were more susceptible than wild-type mice (Jia et al., 2004). The hepatic comet scores of MT-I/II null mice treated with $\mathrm{B}[a] \mathrm{P}$ have a greater tendency to high score than wild-type mice in the present study.

The major metabolic active pathway of $\mathrm{B}[a] \mathrm{P}$ proceeds through trans-dihydrodiol to anti-diol epoxide which alkylates the $N^{2}$ group of guanosine, and BPDE$N^{2}-\mathrm{dG}$, which is the major adduct formed, is associated with $\mathrm{B}[a] \mathrm{P}$ carcinogenesis (Culp and Beland, 1994). In addition, during metabolic processes, $\mathrm{B}[a] \mathrm{P}$ also produces various quinone derivatives and ROS which are mutagens and carcinogens (Penning et al., 1996). Formation of 8-OHdG has been widely used as a biomarker of oxidative DNA damage (Kasai et al., 1987). 8-OHdG is thought to be a promutagenic lesion because this lesion induces G:C to T:A transversion unless repaired prior to replication (Cheng et al., 1992). It has been suggested that organ-specific tumorigenesis may be related to formation of $8-\mathrm{OHdG}$ in the target organs of animals treated with free radical generating carcinogens (Cho et al., 1993). Oral administration of $\mathrm{B}[a] \mathrm{P}$ to Sprague-Dawley rats increased hepatic $8-\mathrm{OHdG}$ and decreased catalase and superoxide dismutase activities. (Kim and Lee, 1997). Our results showed that susceptibility to oxidative DNA damage induced by $\mathrm{B}[a] \mathrm{P}$ was extremely increased in MT-I/II null mice.

In the present study we found that MT plays an important role in defense against $\mathrm{B}[a] \mathrm{P}$-caused genotoxicity such as chromosomal aberration, DNA strand breaks and oxidative DNA damage. By considering the peak times of $\mathrm{B}[a] \mathrm{P}$-induced DNA damage in three genotoxicity assays, the oxidative DNA damage occurred at first, then the DNA strand breaks, and finally, chromosomal aberration.
In addition, at the highest dose $(750 \mathrm{mg} / \mathrm{kg})$ of $\mathrm{B}[a] \mathrm{P}$, two out of five MT-I/II null mice died within $48 \mathrm{hr}$ after $\mathrm{B}[a] \mathrm{P}$ administration. Park et al. (2001) have reported that MTI/II null mice were susceptible to cadmium and other metal-mediated lethalities. Thus, MT may protect against the lethality of $\mathrm{B}[a] \mathrm{P}$.

$\mathrm{B}[a] \mathrm{P}$ itself is chemically inert and requires metabolic activation by $\mathrm{P} 450 \mathrm{~s}$ and epoxide hydrolase in order to react with cellular DNA. $\mathrm{B}[a] \mathrm{P}$ is first oxidized by $\mathrm{P} 450 \mathrm{~s}$ to form intermediate metabolites, $\mathrm{B}[a] \mathrm{P}-7,8$-epoxide, and these epoxides are hydrolyzed by epoxide hydrolase to form $\mathrm{B}[a] \mathrm{P}-7,8$-diol metabolites. $\mathrm{B}[a] \mathrm{P}-7,8$-diols are oxidized again by $\mathrm{P} 450$ s to form highly reactive diolepoxides that cause initiation of cancers in several organs (Conney, 1982). $\mathrm{B}[a] \mathrm{P}$ is also known to induce CYP1A1, CYP1A2 and CYP1B1 through an arylhydrocarbon receptor-dependent mechanism (Shimada et al., 2002). Thus, we attempted to reveal whether MT affects the metabolic activation of $\mathrm{B}[a] \mathrm{P}$ through $\mathrm{P} 450$ s. There was no significant difference in hepatic CYP1A activities between MT$\mathrm{I} / \mathrm{II}$ null mice and wild-type mice with or without $\mathrm{B}[a] \mathrm{P}$ treatment. The present results suggest that MT does not affect metabolic activation of $\mathrm{B}[a] \mathrm{P}$.

On the other hand, the synthesis of MT is induced by many metals, hormones, cytokines, stresses and chemicals (Miles et al., 2000; Sato and Bremner, 1993; Cai et al., 1999). In the present study, it was first found that $\mathrm{B}[a] \mathrm{P}$ can induce MT in the liver. The hepatic MT levels in the wild-type mice were elevated at $6 \mathrm{hr}$ and maintained until $24 \mathrm{hr}$ after $\mathrm{B}[a] \mathrm{P}$ administration. Therefore, $\mathrm{B}[a] \mathrm{P}$-caused genotoxicity such as oxidative DNA damage and DNA strand breaks in the liver may be prevented by not only endogenous MT but also B $[a] \mathrm{P}$-induced MT.

Recently, MT-I/II null mice have been used to study the role of MT in the carcinogenesis of various mutagens. Zhang et al. (1998) have found that MT-I/II null mice were very sensitive to skin carcinogenesis caused by a single topical application of DMBA. Suzuki et al. (2003) have also demonstrated that MT-I/II null mice were sensitive to DMBA/12-O-tetradecanoylphorbol-13-acetateinduced two-stage skin carcinogenesis. In addition, Kondo et al. (1999) have reported that MT-I/II null mice had a high incidence of urinary bladder tumors induced by $N$ butyl- $N$-(4-hydroxybutyl)nitrosamine. These reports suggest that MT-I/II null mice are extraordinarily susceptible to chemical carcinogens. $\mathrm{B}[a] \mathrm{P}$ can induce various tumors such as mammary, uterine, lung, skin, liver, stomach, esophagus and leukemia depending on routes of administration and animal species (IARC monographs, in preparation). The present study revealed that MT-I/II null mice have an increased susceptibility to DNA dam- 
Protection from DNA damage by metallothionein

age caused by $\mathrm{B}[a] \mathrm{P}$ oral administration. MT may prevent $\mathrm{B}[a] \mathrm{P}$-induced carcinogenesis because MT prevents $\mathrm{B}[a] \mathrm{P}$-induced DNA damage.

The mechanism of the protective role of $\mathrm{MT}$ in $\mathrm{B}[a] \mathrm{P}-$ induced DNA damage is unknown. However, its mechanism is related to DNA adduct formation and oxidative DNA damage. MT is a potent antioxidant to various oxidative injuries from ROS in vivo (Satoh et al., 1988, 1992; Sato and Bremner, 1993; Cai et al., 1999). Thus, it is thought that prevention of $\mathrm{B}[a] \mathrm{P}$-induced DNA damage by MT may be due to scavenging of the ROS generated by $\mathrm{B}[a] \mathrm{P}$.

\section{ACKNOWLEDGMENT}

The authors thank Dr. Chiharu Tohyama (The University of Tokyo) for providing the MT-I/II null mice.

\section{REFERENCES}

Cai, L., Klein, J.B. and Kang, Y.J. (2000): Metallothionein inhibits peroxynitrite-induced DNA and lipoprotein damage. J. Biol. Chem., 275, 38957-38960.

Cai, L., Satoh, M., Tohyama, C. and Cherian, M.G. (1999): Metallothionein in radiation exposure: its induction and protective role. Toxicology, 132, 85-98.

Cheng, K.C., Cahill, D.S., Kasai, H., Nishimura, S. and Loeb, L.A. (1992): 8-hydroxyguanine, an abundant form of oxidative DNA damage, causes G----T and A----C substitutions. J. Biol. Chem., 267, 166-172.

Cherian, M.G., Howell, S.B., Imura, N., Klaassen, C.D., Koropatnick, J., Lazo, J.S. and Waalkes, M.P. (1994): Contemporary Issues in Toxicology : Role of metallothionein in carcinogenesis. Toxicol. Appl. Pharmacol., 126, 1-5.

Cherian, M.G., Jayasurya, A. and Bay, B.H. (2003): Metallothioneins in human tumors and potential roles in carcinogenesis. Mutat. Res., 533, 201-209.

Cho, D.H., Hong, J.T., Chin, K., Cho, T.S. and Lee, B.M. (1993): Organotropic formation and disappearance of 8-hydroxydeoxyguanosine in the kidney of Sprague-Dawley rats exposed to adriamycin and $\mathrm{KbrO}_{3}$. Cancer Lett., 74, 141-145.

Conney, A.H. (1982): Induction of microsomal enzymes by foreign chemicals and carcinogenesis by polycyclic aromatic hydrocarbons: G. H. A. Clowes Memorial Lecture. Cancer Res., 42, 4875-4917.

Culp, S.J. and Beland, F.A. (1994): Comparison of DNA adduct formation in mice fed coal tar or benzo[a]pyrene. Carcinogenesis, 15, 247-252.

Duncan, J.R. and Dreosti, I.E. (1975): Zinc intake, neoplastic DNA synthesis, and chemical carcinogenesis in rats and mice. J. Natl. Cancer Inst., 55, 195-196.

Fairbairn, D.W., Olive, P.L. and O'Neill, K.L. (1995): The comet assay: a comprehensive review. Mutat. Res., 339, 37-59.

Hayashi, M., Morita, T., Kodama, Y., Sofuni, T. and Ishidate, M.Jr. (1990): The micronucleus assay with mouse peripheral blood reticulocytes using acridine orange-coated slides. Mutat. Res., 245, 245-249.

IARC working group on the evaluation of carcinogenic risks to humans. Air pollution, Part 1, some non-heterocyclic polycyclic aromatic hydrocarbons and some related industrial exposure. IARC Monogr. Eval. Carcinog. Risks Hum. 92. in preparation.

Itoh, S. and Shimada, H. (1996): Micronucleus induction by chromium and selenium, and suppression by metallothionein inducer. Mutat. Res., 367, 233-236.

Jia, G., Sone, H., Nishimura, N., Satoh, M. and Tohyama, C. (2004): Metallothionein (I/II) suppresses genotoxicity caused by dimethylarsinic acid. Int. J. Oncol., 25, 325-333.

Kasai, H., Nishimura, S., Kurokawa, Y. and Hayashi, Y. (1987): Oral administration of the renal carcinogen, potassium bromate, specifically produces 8-hydroxydeoxyguanosine in rat target organ DNA. Carcinogenesis, 8, 1959-1961.

Kim, K.B. and Lee, B.M. (1997): Oxidative stress to DNA, protein, and antioxidant enzymes (superoxide dismutase and catalase) in rats treated with benzo(a)pyrene. Cancer Lett., 113, 205-212.

Kondo, Y., Himeno, S., Endo, W., Mita, M., Suzuki, Y., Nemoto, K., Akimoto, M., Lazo, J.S. and Imura, N. (1999): Metallothionein modulates the carcinogenicity of $\mathrm{N}$-butyl- $\mathrm{N}$-(4hydroxybutyl)nitrosamine in mice. Carcinogenesis, 20, 16251627.

Michalska, A.E. and Choo, K.H. (1993): Targeting and germ-line transmission of a null mutation at the metallothionein I and II loci in mouse. PNAS, 90, 8088-8092.

Miles, A.T., Hawksworth, G.M., Beattie, J.H. and Rodilla, V. (2000): Induction, regulation, degradation, and biological significance of mammalian metallothioneins. Crit. Rev. Biochem. Mol. Biol., 35, 35-70.

Naganuma, A., Satoh, M. and Imura, N. (1987): Prevention of lethal and renal toxicity of cis-diamminedichloroplatinum (II) by induction of metallothionein synthesis without compromising its antitumor activity in mice. Cancer Res., 47, 983-987.

Nakagawa, I., Nishi, E., Naganuma, A. and Imura, N. (1995): Effect of preinduction of metallothionein synthesis on clastogenicity of anticancer drugs in mice. Mutat. Res., 348, 37-43.

Nishimura, H., Nishimura, N. and Tohyama, C. (1990): Localization of metallothionein in the genital organs of the male rat. J. Histochem. Cytochem., 38, 927-933.

Park, J.D., Liu, Y. and Klassen, C.D. (2001): Protective effect of metallothionein against the toxicity of cadmium and other metals. Toxicology, 163, 93-100.

Penning, T.M., Ohnishi, S.T., Ohnishi, T. and Harvey, R.G. (1996): Generation of reactive oxygen species during the enzymatic oxidation of polycyclic aromatic hydrocarbon trans-dihydrodiols catalyzed by dihydrodiol dehydrogenase. Chem. Res. Toxicol., 9, 84-92.

Poswillo, D.E. and Cohen, B. (1971): Inhibition of carcinogenesis by dietary zinc. Nature (London, U. K.), 231, 447-448.

Poulsen, H.E., Prieme, H. and Loft, S. (1998): Role of oxidative DNA damage in cancer initiation and promotion. Eur. J. Cancer Prev., 7, 9-16.

Sasaki, Y.F., Nishidate, E., Izumiyama, F., Matsusaka, N. and Tsuda, S. (1997): Simple detection of chemical mutagens by the alkaline single-cell gel electrophoresis (Comet) assay in multiple mouse organs (liver, lung, spleen, kidney, and bone marrow). Mutat. Res., 391, 215-231.

Sato, M. and Bremner, I. (1993): Oxygen free radicals and metallothionein. Free Radic. Biol. Med., 14, 325-337.

Satoh, M., Kondo, Y., Mita, M., Nakagawa, I., Naganuma, A. and Imura, N. (1993): Prevention of carcinogenicity of anticancer drugs by metallothionein induction. Cancer Res., 53, 4767-4768. Satoh, M., Naganuma, A. and Imura, N. (1988): Involvement of car- 
diac metallothionein in prevention of adriamycin induced lipid peroxidation in the heart. Toxicology, 53, 231-237.

Satoh, M., Naganuma, A. and Imura, N. (1992): Effect of preinduction of metallothionein on paraquat toxicity in mice. Arch. Toxicol., 66, 145-148.

Shimada, H., Suzuki, H., Itoh, S., Hattori, C., Matsuura, Y., Tada, S. and Watanabe, C. (1992): The micronucleus test of benzo $[a]$ pyrene with mouse and rat peripheral blood reticulocytes. Mutat. Res., 278, 165-168.

Shimada, T., Inoue, K., Suzuki, Y., Kawai, T., Azuma, E., Nakajima, T., Shindo, M., Kurose, K., Sugie, A., Yamagishi, Y., FujiiKuriyama, Y. and Hashimoto, M. (2002): Arylhydrocarbon receptor-dependent induction of liver and lung cytochromes $\mathrm{P} 450$ 1A1, 1A2, and 1B1 by polycyclic aromatic hydrocarbons and polychlorinated biphenyls in genetically engineered C57BL/ $6 \mathrm{~J}$ mice. Carcinigenesis, 23, 1199-1207.

Shimada, T., Wunsch, R.M., Hanna, I.H., Sutter, T.R., Guengerich, F.P. and Gillam, E.M.J. (1998): Recombinant human cytochrome P450 1B1 expression in Escherichia coli. Arch. Biochem. Biophys., 357, 111-120.
Singh, N.P., McCoy, M.T., Tice, R.R. and Schneider, E.L. (1988): A simple technique for quantitation of low levels of DNA damage in individual cells. Exp. Cell Res., 175, 184-191.

Suzuki, J.S., Nishimura, N., Zhang, B., Nakatsuru, Y., Kobayashi, S., Satoh, M. and Tohyama, C. (2003): Metallothionein deficiency enhances skin carcinogenesis induced by 7,12-dimethylbenz $[a]$ anthracene and 12-O-tetradecanoylphorbol-13-acetate in metallothionein-null mice. Carcinogenesis, 24, 1123-1132.

Tohyama, C. and Shaikh, Z.A. (1981): Metallothionein in plasma and urine of cadmium-exposed rats determined by a single-antibody radioimmunoassay. Fundam. Appl. Toxicol., 1, 1-7.

Waalkes, M.P., Liu, J., Goyer, R. and Diwan, B.A. (2004): Metallothionein-I/II double knockout mice are hypersensitive to leadinduced kidney carcinogenesis: role of inclusion body formation. Cancer Res., 64, 7766-7772.

Zhang, B., Satoh, M., Nishimura, N., Suzuki, J.S., Sone, H., Aoki, Y. and Tohyama, C. (1998): Metallothionein deficiency promotes mouse skin carcinogenesis induced by 7,12-dimethylbenz $[a]$ anth racene. Cancer Res., 58, 4044-4046. 